Kocaeli Üniversitesi Sağlık Bilimleri Dergisi

\title{
EVALUATION OF HEMATOLOGICAL CHANGES IN PATIENTS WITH BRUCELLOSIS
}

\author{
BRUSELLOZ HASTALARINDA HEMATOLOJIK DE ĞISSIKLIKLER
}

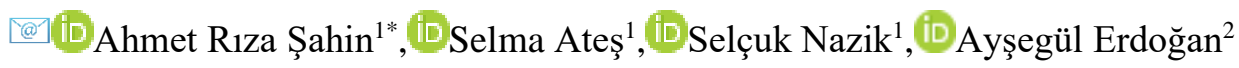

${ }^{1}$ Kahramanmaraş Sutcu Imam University, Faculty of Medicine, Department of Clinical Microbiology and Infectious Diseases, Turkey

${ }^{2}$ Kahramanmaras Sutcu Imam University, Faculty of Medicine, Department of Public Health, Turkey

ORCID iD: Ahmet Rıza Şahin: 0000-0002-4415-076X; Selma Ateş: 0000-0002-2515-8578; Selçuk Nazik: 0000-0003-0587-0104;

Ayşegül Erdoğan: 0000-0002-0548-5911

*Corresponding Author/Sorumlu Yazar: Ahmet Rıza Şahin, e-mail / e-posta: drahmetrizasahin@gmail.com

Received / Geliş Tarihi: 17.05 .2019

Accepted / Kabul Tarihi: 30.08 .2019

Published / Yaymm Tarihi: 06.09.2019

\begin{abstract}
Objective: Brucellosis is a zoonotic infectious disease of domestic and wild animals caused by Brucella strains and is transmitted to humans by various routes. Brucellosis is an important problem leading to economic losses due to high morbidity rates. Although the disease has been eradicated in most developed countries it remains a public problem especially in the Mediterranean countries of the Middle East and Africa. The objective of this study was to investigate hematological changes in patients with brucellosis from Kahramanmaraş in light of the literature.

Methods: A total of 197 patients diagnosed with brucellosis and followed-up in the infectious diseases clinics of Kahramanmaraş Sütçü İmam University Hospital between 1 January 2012 and 31 December 2017 were retrospectively evaluated for hematological changes. Demographic and epidemiologic data of the patients including age, gender, profession, the habit of consuming fresh cheese, and contact with animals were recorded. Hematological changes were considered as leukopenia (leukocyte count $4.000 / \mu \mathrm{L}$ ), anemia (hemoglobin concentration $<12 \mathrm{~g} / \mathrm{dL}$ in women and $<13$ $\mathrm{g} / \mathrm{dL}$ in men), and thrombocytopenia (platelet count $<150.000 / \mu \mathrm{L}$ ).

Results: Sixty eight percent of the patients developed hematological changes. No significant difference was found between the patients with and without hematological changes in terms of age and sex. The most common hematological changes was anemia in $36.5 \%$ of the patients followed by thrombocytopenia by (11.7\%), leukopenia (10.2\%) and leucocytosis $(9.6 \%)$.

Conclusion: Hematological changes are among the most common changes of brucellosis. Diagnostic tests for brucellosis should be kept in mind in cases of hematological anomalies including anemia, leukopenia, thrombocytopenia and pancytopenia in endemic regions.
\end{abstract}

Keywords: Anemia, Brucella, brucellosis

$\ddot{\mathbf{O z}}$

Amaç: Bruselloz, Brucella türlerinin neden olduğu zoonotik bir enfeksiyon hastalığıdır. Bruselloz yüksek morbidite oranları nedeniyle ekonomik kayıplara yol açan önemli bir problemdir. Hastalı̆̆ın yayılımı çoğu gelişmiş ülkede engellenmiş olmakla birlikte özellikle Ortadoğu ve Afrika'daki Akdeniz ülkelerinde bir halk sağlığı problemi olarak devam etmektedir. Bu çalışmanın amacı, Kahramanmaraş ilinde brusellozlu hastalarda hematolojik değişiklikleri literatür eşliğinde araştırmaktır.

Yöntem: 1 Ocak 2012 ile 31 Aralık 2017 tarihleri arasında bruselloz tanısı konulan ve Kahramanmaraş Sütçü İmam Üniversite hastanesinin enfeksiyon hastalıkları kliniğinde takip edilen 197 hasta, hematolojik komplikasyonlar açısından geriye dönük olarak değerlendirilmiştir. Yaş, cinsiyet, meslek, taze peynir tüketimi alışkanlığı ve hayvanlarla temas gibi hastaların demografik ve epidemiyolojik verileri kaydedilmiştir. Hematolojik komplikasyonlar lökopeni $(<4000 / \mu \mathrm{L})$, anemi (hemoglobin derişiminin kadınlarda $<12 \mathrm{~g} / \mathrm{dL}$, erkeklerde $<13 \mathrm{~g} / \mathrm{dL}$ olmasi) ve trombositopeni ( $<150000$ $\mu \mathrm{L})$ olarak kabul edilmiştir.

Bulgular: Hastaların \%68'inde hematolojik değişiklikler gelişmiştir. Hematolojik komplikasyon bulunan hastalar arasında yaş ve cinsiyet açısından anlamlı fark yoktur. En yaygın hematolojik komplikasyon ortalama 12,3 $\pm 2,1$ hemoglobin derişimi ile hastaların \%36,5'inde anemi olup, bunu \% $\% 11,7$ ile trombositopeni, \%10,2 ile lokopeni ve \%9,6 ile lokositoz izlemiştir.

Sonuç: Hematolojik değişiklikler brusellozda en yaygın komplikasyonlar arasındadır. Endemik bölgelerde anemi, lökopeni, trombositopeni ve pansitopeni dahil olmak üzere hematolojik laboratuvar anormallik durumlarında bruselloz için tanısal testler akılda tutulmalıdır.

Anahtar Kelimeler: Anemi, Brucella, bruselloz 


\section{Introduction}

Brucellosis is a disease, which has been found to be caused by Brucella strains a century ago. It is a zoonotic infectious disease of domestic and wild animals, which is transmitted to humans by several routes. ${ }^{1}$ Brucella spp. are gram-negative, non-motile and non-spore-forming small coccobacilli. ${ }^{2}$ Brucella spp. is highly sensitive to heat, ionized radiation, and disinfecting agents. ${ }^{1,3}$ Six species have been identified including B. abortus, B. melitensis, B. suis, and B. canis that cause brucellosis in humans as well as B. ovis and $B$. neotomae. These six species have been proposed to be classified under one (B. maris) or two (B. pinnipediae and B. cetaceae). ${ }^{4,5}$ The most commonly isolated Brucella species in Turkey is $B$. melitensis. ${ }^{6}$

Though spreaded worldwide, it is more commonly seen in the Mediterranean countries of Middle East and Africa. ${ }^{3,6}$ Brucellosis is an important problem leading to economic losses with low mortality, but high morbidity rates. ${ }^{7}$ England, Netherlands, Germany, Austria, Denmark, Finland, Sweden, Norway, and Luxembourg have officially completed the Brucella eradication. France, the largest agriculture country of Europe, and other European countries including Greece, Iceland, Portugal, and Spain are continuing the eradication program successfully. ${ }^{8}$ The eradication program in Turkey, which had started 30 years ago once failed and was renewed in 2009. 6,8

Brucellosis is transmitted to humans by direct or indirect contact with an infected animal. ${ }^{3}$ Primarily it is transmitted through consumption of unboiled, unpasteurized dairy products such as milk, cheese and butter. Transmission may occur through contact of disintegrated skin through infected excreta, direct inoculation to conjunctiva, aerosol inhalation by laboratory staff, and contact with sea mammals. ${ }^{6}$ Brucellosis is a disease, which may involve systems and multiple organs, and may be recognized by means of different clinical manifestations. ${ }^{7}$ Brucella spp. may cause lymphoreticular (bone marrow, liver, spleen, lymph nodes) involvement. ${ }^{7,9}$ This often results in hematological changes. ${ }^{9}$

In this study, we aimed to investigate hematological changes that developed in patients with brucellosis who were followedup in our hospital, situated in a region where brucellosis is common, in comparison with the literature.

\section{Methods}

Epidemiological features, clinical data, and laboratory values of patients diagnosed with brucellosis who were followed-up in the infectious diseases outpatient clinics and inpatient wards of Kahramanmaraş Sütçü İmam University Hospital between 1 January 2012 and 31 December 2017 were investigated from the patient files and evaluated in terms of hematological changes. Patients' demographic and epidemiologic data such as age, gender, profession, consumption of fresh cheese, and contact with animals were recorded. The diagnosis of brucellosis was based on detection of a titer $\geq 1 / 160$ in the standard tube agglutination test (STA), or isolation of Brucella spp. in any culture. Patients' $\mathrm{C}$ reactive protein (CRP) and erythrocyte sedimentation rate (ESR) were recorded as inflammatory markers. In order to define hematological changes; while a leococyte count of $>10 \quad 000 / \mu \mathrm{L}$ was considered as leucocytosis; a leucocyte count of $<4000 / \mu \mathrm{L}$, a hemoglobin value $<12 \mathrm{~g} / \mathrm{dL}$ in women and $<13 \mathrm{~g} / \mathrm{dL}$ in men, and a platelet count $<150 \quad 000 / \mu \mathrm{L}$ was considered as leukopenia, anemia and thrombocytopenia, respectively. CRP was studied with turbidimetric method and values of $>6 \mathrm{mg} / \mathrm{dL}$ are considered as pathologic.

\section{Statistical Analysis}

Statistical analysis of the data was performed using SPSS 15.0 package software. Shapiro Wilk test was used to assess whether the parameters fit normal distribution. Chi-square test was used in statistical analysis of paired variables. Descriptive statistics for the continuous and orderable variables were expressed as mean, standard deviation, and median (minimummaximum), while categorical variables were given as percentages. $p$ values $<0.05$ were considered statistically significant.

\section{Results}

Among 346 patients diagnosed with brucellosis, 197 patient with complete epidemiological, clinical and laboratory data were included in this study. The standard tube agglutination tests of all patients were positive with values $\geq 1 / 160$. Of the patients, $42.1 \%(n=83)$ were male, and $57.9 \%(n=114)$ were female with a mean age of $49.61 \pm 19.07$ years. As for the season of presentation, $51.3 \%(n=101), 22.3 \%(n=44), 19.7 \%$ $(n=39)$, and $13.7 \%(n=27)$ of patients presented in summer, spring, autumn, and winter, respectively. Of the patients diagnosed with brucellosis, $71.6 \%(n=141)$ were living in rural areas, and $28.4 \%(n=56)$ in urban areas. The most common possible transmission was consumption of fresh cheese $(77 \%)$ $(\mathrm{n}=153)$, followed by animal feeding $(68.5 \%)(\mathrm{n}=135)$, and consumption of raw meat $(43.6 \%)(n=86)$.

The changes in hematological parameters developed in $52 \%$ $(n=104)$ of the patients. Of the patients who developed hematological changes, $42.3 \%(n=44)$ were male, and $57.6 \%$ $(n=60)$ were female with a mean age of $47.5 \pm 17.7$ years. No significant difference was found between the patients with change of hematological parametersin terms of age and gender. The most common hematological finding was anemia (36.5\%) $(\mathrm{n}=72)$ with a mean hemoglobin value of $12.3 \pm 2.1$ (7.3-16.0). This was followed by thrombocytopenia $(11.7 \%)(n=23)$, leukopenia $(10.2 \%)(n=20)$, and leucocytosis $(9.6 \%)(n=19)$. The median values of plateletes and white blood cells were $260.200(\mathrm{~min}=5.000, \max =580.000)$ and $6.600 \quad(\mathrm{~min}=530$, $\max =16.060$ ), respectively. Of the 72 anemic patients, $62.5 \%$ were female. Anemia was identified in $39.5 \%(n=45)$ of female and $32.5 \%(n=27)$ of male patients with brucellosis. Patients were divided into three groups with respect to hemoglobin concentration: $<8 \mathrm{~g} / \mathrm{dL}, 8-10 \mathrm{~g} / \mathrm{dL}$, and $>10$. There were two (one male, one female), 12 ( 1 male, 11 female), and 59 (26 male, 33 female) patients in the groups, respectively. The incidence of anemia was higher in female than in male patients. The prevalence of anemia was found to be $42.4 \%(n=25)$ in premenopausal female patients and $36.4 \% \quad(n=20)$ in postmenopausal female patients with brucellosis. No significant difference was found between the premenopausal and postmenopausal female patients in terms of incidence of anemia $(p=0.512)$ (Table 1$)$. When laboratory values of the patients who developed hematological changes were evaluated; the mean CRP was found as $43.7 \pm 26.5$ (range: 12.5 112 ), and the mean ESR was found as $39.1 \pm 26.4$ (range: 2138). 
Table 1. Comparison of female patients in reproductive age/menopausal period in terms of anemia

\begin{tabular}{cccc}
\hline & $\begin{array}{c}\text { Patinets with } \\
\text { anemia }\end{array}$ & $\begin{array}{c}\text { Patients without } \\
\text { anemia }\end{array}$ & Total \\
\hline Reproductive age & & & \\
$\quad$ n & 25 & 34 & 59 \\
$\quad \%$ & 42.4 & 57.6 & 100 \\
$\begin{array}{l}\text { Menopausal } \\
\text { period }\end{array}$ & & & \\
$\quad$ n & 20 & 35 & 55 \\
$\%$ & 36.4 & 63.6 & 100 \\
$\begin{array}{c}\text { Total } \\
\text { n }\end{array}$ & & & \\
$\%$ & 45 & 69 & 114 \\
\hline
\end{tabular}

Pearson Chi-Square $\chi 2=0.430 ; p=0.512$

\section{Discussion}

Brucellosis is a common systemic disease, which is seen all the year round in Turkey and is more common during calving period of small cattles and in cheesemaking period (spring and summer). ${ }^{10,11}$ In studies conducted in Turkey, $46-50 \%$ of the patients present in summer months. ${ }^{10,11}$ Seasonal distribution of the cases in our study was consistent with the literature.

Veterinarians and laboratory personnel constitute the occupational risk groups for brucellosis in developed countries whereas in developing countries; persons dealing with animal husbandry, those living in rural areas, and individuals consuming unpasteurized milk and cheese are more commonly diagnosed with brucellosis. ${ }^{7,12}$ In the study by Demir et al., $76.8 \%$ of the patients were living in rural areas. ${ }^{11}$ This ratio was $80 \%$ in the study by Gursoy et al. ${ }^{13}$ In the present study, $71.6 \%(n=141)$ were living in rural areas, $68.5 \%(n=135)$ were dealing with animal husbandry, and $77.7 \%(\mathrm{n}=153)$ had a history of unpasteurized dairy products consumption.

Patients can be classified as acute, subacute, and chronic based on disease onset. Lack of these data in our study may be considered as a limitation. Our results were consistent with the literature in terms of profession, living in rural areas, and consumption of raw milk habits. One patient used to consume raw meat. Ulug et al. reported raw meat as a risk factor for brucellosis in their study which is conducted in Turkey.

There is no difference of gender in distribution of cases reported from Turkey. ${ }^{13-15}$ In a study by Abdi-Liae in the Middle East, male patients outnumbered females. ${ }^{16}$ There are studies in Turkey reporting more female patients because of women's dealing with animal care, milking, and cheesemaking. ${ }^{17,18}$ In the study period, we encountered a total of 114 female patients - a predominance compared to the male patients, and a higher proportion of female gender compared to other studies ${ }^{14,15}$.

The best-known clinical involvement of brucellosis is in the locomotor system followed by gastrointestinal and hematological systems. ${ }^{18-20}$ Studies in the literature have often reported hematological changes of brucellosis. ${ }^{21}$ The most common laboratory disorders have been reported also in the hematological system. ${ }^{14}$ In a study of 233 patients by Akdeniz et al. leucopenia, anemia, thrombocytopenia, and pancytopenia were seen in $21 \%, 44 \%, 26 \%$, and $8 \%$ patients, respectively. ${ }^{22}$ In a study of 38 cases by Crosby et al., the same abnormalities were detected in $45 \%, 74 \%, 39.5 \%$, and $21 \%$, respectively. ${ }^{23}$ In our study, while hematological deteriorations such as thrombocytopenia and leukopenia were observed, severe leucopenia cases were rare. Consistently with the literature, anemia was the most common changes in our study. Of our anemic patients, $60 \%(n=27)$ were in the reproductive ages, and anemia, which is encountered in 15-47 years of age in Turkey, may not be associated with brucellosis. ${ }^{24,25}$

The studies before 2000 have reported the incidence of anemia between $55-74 \%$, while the studies published after 2000 have reported this incidence as $14.2-43 \%$ (Table 2).,10,22,23,26-29 This decrease might be due to awareness training, increasing number of healthcare facilities, and close obstetric follow-up. ${ }^{25}$ Our study seems to be consistent with the literature data published after 2000 .

Table 2. Incidence of anemia in the studies conducted before and after 2000

\begin{tabular}{ccccc}
\hline Year & Authors & Country & Rate of anemia & Number of cases \\
\hline 2003 & Namiduru $^{26}$ & Turkey & 36.8 & 120 \\
1998 & Akdeniz $^{22}$ & Turkey & 55 & 233 \\
2010 & Uluğ $^{10}$ & Turkey & 43 & 78 \\
2007 & Gül $^{27} *$ & Turkey & 14.2 & 140 \\
2010 & Buzgan $^{7}$ & Turkey & 40.3 & 1028 \\
2005 & Yüce $^{28}$ & Turkey & 29.1 & 55 \\
2010 & Demir $^{29}$ & Turkey & 26.5 & 83 \\
1995 & Aygen $^{20}$ & Turkey & 62.8 & 183 \\
1984 & Crosby $^{23}$ & Peru & 74 & 38 \\
\hline
\end{tabular}

* Since the research was carried out in a military hospital, all patients were male.

Hemophagocytosis, hypersplenism, and granulomas in bone marrow are thought to play major roles in the development of hematological changes in patients with brucellosis. ${ }^{30}$ Rarely bleeding has been associated with intravascular hemolysis and autoimmune mechanisms. ${ }^{23,32}$ Bleeding and purpura may be seen secondary to severe thrombocytopenia and coagulopathies in brucellosis cases. $^{3}$ In our study, thrombocytopenia was severe in one of the 23 patients with thrombocytopenia. The changes in hematological parameters may mimic primary hematological disorders, malignancies, thus lead to delayed diagnosis of brucellosis. ${ }^{32}$ In our study, the patients had presented to other healthcare centers before getting the diagnosis of brucellosis in our hospital.

In conclusion, hematological manifestations are among the most common laboratory findings in brucellosis. Since brucellosis symptoms are nonspecific, a detailed history should be taken. It should be kept in mind that brucellosis may be confused with other diseases and malignancies. The hematologic laboratory abnormalities (leukopenia, anemia, thrombocytopenia or pancytopenia) observed in an endemic region should prompt the physician to order diagnostic tests for brucellosis.

\section{Acknowledgments}

None declared

\section{Conflict of Interest}

No conflict of interest was declared by the authors.

\section{Compliance of Ethical Statement \\ Ethical Approval}

Ethical approval for the study was granted by the Clinical Research Ethics Committee of Kahramanmaraş Sütçü İmam University Faculty of Medicine (Decision Number: 322, Decision Date: 25.07.2018). No patient consent was obtained since the study was conducted retrospectively.

\section{Financial Disclosure/Funding}

The authors declared that this study has received no financial support. 


\section{Author Contributions}

ARŞ: Critical revision; data analysis and interpretation; data collection; literature search, resources, materials; manuscript drafting/writing/editing; study design and conception; supervision, SA: Critical revision; study design, SN: Critical revision; data collection; data analysis and interpretation, AE: Data analysis and interpretation; supervision.

\section{References}

1. Young EJ. Brucella species. In: Mandell GL, Douglas RG, Bennett JE eds. Mandell, Douglas and Bennett's Principles and Practice of Infectious Diseases. 8th ed. Philadelphia: Churcill Livingstone Elsevier, 2015:2583-2589.

2. Black FT. Brucellosis. Eds.:Cohen J, Powderly W: Infectious Diseases. 2nd edition. Edinburgh: Elsevier Limited, 2004: p. $1665-1668$.

3. Alp E, Doğanay M. Bruselloz. Willke Topcu A, Soyletir G, Doğanay M. Infeksiyon Hastalıklarl ve Mikrobiyolojisi. 4. bask1. İstanbul; Nobel Basımevi; 2017:863-872.

4. Jahans KL, Foster G, Broughton ES. The characterisation of Brucella strains isolated from marine mammals. Vet Microbiol.1997;57:373-382.

5. Cloeckaert A, Verger JM, Grayon M, et al. Classification of Brucella spp. İsolated from marine mammals by DNA polymorphism at the omp2 locus. Microbes Infect. 2001;3:729738.

6. Mamıkoğlu L. Bruselloz. In: Ulusoy S, Leblebicioğlu H, Arman D, Onemli ve Sorunlu Gram-Negatif Bakteri İnfeksiyonları. 2. bask1. Ankara: Bilimsel Tip Yayınevi, 2012: 407-444.

7. Buzgan T, Karahocagil MK, Irmak H, Baran Aİ, Karsen H, Evirgen O. Clinical manifestations and changes in 1028 cases of brucellosis: A retrospective evaluation and review of the literature. Int $J$ Infect Dis. 2010;14(6):e469-748. doi:10.1016/j.ijid.2009.06.031.

8. Pappas G, Papadimitriou P, Akritidis N, Christou L, Tsianos EV. The new global map of human brucellosis. The Lancet infectious diseases. 2006:6(2);91-99.

9. Bourantas LK, Pappas G, Kapsali E, Gougopoulou D, Papamichail D, Bourantas KL. Brucellosis induced autoimmune hemolytic anemia treated with rituximab. Ann Pharmacother. 2010;44(10):1677-1680. doi:10.1345/aph.1P249.

10. Ulug M, Ulug NC. Brusellozlu 78 Olgunun Degerlendirilmesi/Evaluation of 78 Cases with Brucellosis. Klimik Derg. 2010;23(3):89.

11. Demir MI, Kader C, Colak NY, Kocabıyık O, Erbay A, Gok ŞE. Bruselloz Olgularının Değerlendirilmesi Evaluation of Brucellosis Cases. Bozok Tip Dergisi. 2017;7(3):47-51.

12. El-Koumi, Mohamed A., Mona Afify, and Salha H. Al-Zahrani. A prospective study of brucellosis in children: relative frequency of pancytopenia. Mediterr $J$ Hematol Infect Dis. 2013;5(1):e2013011. doi:10.4084/MJHID.2013.011

13. Gursoy B, Tekin-Koruk S, Sirmatel F, Karaağac L. Bruselloz: 140 olgunun değerlendirilmesi. Klimik Derg. 2008;21(3):101-114.

14. Kaya O, Akcam FZ, Avşar K, Tiğlı A, Yaylı G. Bruselloz: 75 olgunun klinik ve laboratuvar verilerinin değerlendirilmesi. Türkiye Klinikleri Tip Bilimleri Dergisi. 2006;26(6):623-629.
15. Gur A, Geyik MF, Dikici B, et al. Changes of brucellosis in different age groups: A study of 283 cases in southeastern Anatolia of Turkey. Yonsei Med J. 2003;44(1):33-44.

16. Abdi-Liae Z, Soudbakhsh A, Jafari S, Emadi H, Tomaj K. Haematological manifestations of brucellosis. Acta Medica Iranica. 2007;45(2):145-148.

17. Sacar S, Hircin-Cenger D, Toprak S, Demir M, Turgut H. Otuz bruselloz olgusunun klinik değerlendirilmesi. Infeks Derg. 2008;22(1):11-14.

18. Koşar A, Aygunduz M, Yaylı G. İkiyuzseksen bruselloz olgusunda farklı iki tedavinin karşılaştırılması. Infeks Derg. 2001;15(4):433-437.

19. Alptekin N, Bilgic A. Brusellozis. Türkiye Klinikleri Fiziksel Tip ve Rehabilitasyon Dergisi. 2003;3(3):97-106

20. Aygen B, Sumerkan B, Kardaş Y, Doğanay M, İnan M. Bruselloz: 183 olgunun değerlendirilmesi. Klimik Derg. 1995;8(1):13-6.

21. Al-Eissa Y, M. Al-Nasser. Haematological manifestations of childhood brucellosis. Infection. 1993;21(1):23-26.

22. Akdeniz H, Irmak H, Seckinli T, Buzgan T, Demiroz AP. Hematological manifestations in brucellosis cases in Turkey. Acta Medica Okayama.1998;52(1):63-65.

23. Crosby, E, Lipsa L, Miro Q, Carillo P,Gotuzzo. Hematologic changes in brucellosis. Journal of Infectious Diseases. 1984;150(3):419-424.

24. Dilek İ, Altun S, Tuncer İ, Uygan İ, Topal C, Aksoy H. Hemoglobin, hematocrit levels, erythrocyte indexes and evaluation of etiological causes in iron deficiency anemia. Van Tip Dergisi. 2000;7(2):51-56.

25. T.C. Sağglık Bakanlığı Ana Cocuk Sağlığı ve Aile Planlaması Genel Mudurluğu. Emzirmenin korunmas1, ozendirilmesi, desteklenmesi ile demir yetersizliği anemisinin onlenmesi ve kontrolu. Ankara, 2004:4-8.

26. Namiduru, M. Gungor K, Dikensoy O, et al. Epidemiological, clinical and laboratory features of brucellosis: a prospective evaluation of 120 adult patients. Int J Clin Pract. 2003;57(1):2024.

27. Gul HC, Coşkun O, Turhan V, et al. Bruselloz: 140 olgunun geriye donuk olarak irdelenmesi. TSK Koruyucu Hekimlik Bülteni. 2007:6(4):249-252.

28. Yuce A, Alp-Cavuş S, Yapar N, Cakır N. Bruselloz: 55 olgunun değerlendirilmesi. Klimik Derg. 2006;19(1):13-7.

29. Demir NA, Ural O. Komplike Olmayan Akut Brusellozlu 83 Olgunun İrdelenmesi. Flora Dergisi. 2010;15:132-138.

30. Pappas G, Akritidis N, Bosilkovski M, Tsianos E. Brucellosis. N Engl J Med. 2005;352(22):2325-2336.

31. Roushan MR, Mohez M, Smailnejad Gangi SM, Soleimani Amiri MJ, Hajiahmadi M. Epidemiological features and clinical manifestations in 469 adult patients with brucellosis in Babol, Northern Iran. Epidemiology \& Infection. 2004;132(6):11091114.

32. Aygen, B, Doğanay M, Sumerkan B, Yıldız O. Clinical manifestations, changes and treatment of brucellosis: a retrospective evaluation of 480 patients. Medecine et maladies infectieuses. 2002;32(9):485-493. 